\title{
IMPLEMENTASI KEBIJAKAN TERHADAP KINERJA PEGAWAI DI KANTOR SATUAN POLISI PAMONG PRAJA KABUPATEN SUBANG \\ (Studi Implementasi Kebijakan Mengenai Peraturan Daerah Kabupaten Subang No. 13 Tahun 2006 Tentang Ketertiban, Kebersihan dan Keindahan)
}

\author{
Oleh : \\ Luki Natika \\ Dosen FIA Universitas Subang
}

\begin{abstract}
The basic problem in this research is that low performance of employees in the Office of Civil Service Police Unit Subang district. The Aformantion caused by factors policy implementation has not been implemented optimally.

The research method used is descriptive analysis, namely by describing each variable and tested both variables with a quantitative approach (statistical) which was subsequently analyzed and compared with existing theories and issues to be taken later conclusions.

The results are based by hypothesis states that partial implementation of the policy variables can be detected from the level of influence of each factor consisting of policy implementation $(X)$ is divided into six factors: Standards and Objectives Policies (X1) of $21.3 \%$, Sources power (X2) equal to $14.1 \%$, characteristic of the implementing organizations (X3) amounted to $12.8 \%$, communication between the implementing organization and implementation activities $(X 4)$ of $6.3 \%$, attitude of the implementers (X5) amounted to 9.2\%, socio-economic and political environment (X6) of 7.3\% used the performance of employees in the Office of Civil Service Police Unit Subang district. While the effect can be seen from the simultaneous optimization of factors influence the overall policy implementation (shared). Magnitude of the effect of policy implementation by $71.2 \%$ while other factors not examined (epsilon) but affects the performance of employees amounted to $28.8 \%$

The conclusion of this research is the role of policy implementation is essential to facilitate the employees, in making the performance of each implementation of a policy implementation for the achievement of an order, cleanliness and beauty of the fabric of society.
\end{abstract}

Key Word : Policy Implementation, Employee's Performance 


\section{A. Pendahuluan}

Proses reformasi terus menggelinding, sejalan dengan perubahan dan tuntutan kehidupan masyarakat yang semakin kuat dan perlunya dilakukan penataan berbagai struktur tingkatan institusi yang ada pada setiap organisasi. Terjadinya perubahan politik secara cepat yang berdampak pada ambruknya tatanan ekonomi dan sosial perlu segera dibangun kembali pranata baru yang disesuaikan dengan tuntutan zaman. Dalam pembangunan pranata baru itu, perananan administrasi sangat besar yang telah ditetapkan berbagai kebijakan oleh para elite politik di saat terbentuknya pemerintahan Indonesia yang kuat.

Kepentingan publik merupakan persamaan kebutuhan yang dimiliki oleh setiap anggota masyarakat yang pada umumnya ingin dicapai. Ditinjau dari segi hubungan masyarakat, setiap organisasi baik berupa instansi maupun swasta harus ikut menjaga kepentingan publik. Bila diperhatikan dewasa ini telah dirasakan di mana-mana, bahwa tingkat kesadaran politik masyarakat cenderung semakin meningkat. Hal ini dapat dilihat dari semakin banyaknya orang terlibat dalam partisipasi politik.

Kepentingan publik itu mau tidak mau akan menyangkut pada soal kepentingan pribadi sebagai sumber utama adanya kepentingan umum. Sebab kepentingan umum merupakan suatu bentuk himpunan kepentingan pribadi yang sama dari kelompok orang atau masyarakat, walaupun tidak berarti bahwa setiap kepentingan yang sama dari sekelompok masyarakat otomatis menjadi kepentingan publik. Secara singkat dapat dinyatakan bahwa kepentingan umum atau publik adalah himpunan dari kepentingan pribadi yang telah disublimasikan dan tidak bertentangan dengan norma masyarakat serta aturan yang berlaku.

Seiring dengan perubahan zaman yang ke arah sana semakin berkembang tatanan pemerintah menuju kepemerintahan yang lebih baik, untuk meningkatkan kepentingan publik demi terselengaranya kesejahteraan masyarakat dan kemajuan bangsa Indonesia. Untuk menuju ke arah itu sistem administrasi Negara berkembang terus sesuai dengan faktor lingkungan yang mempengaruhi.

Tatanan pemerintah saat ini mulai dirasakan dengan adanya otonomi daerah di seluruh provinsi atau daerah yang berada di ruang lingkup kesatuan bangsa dan negara Indonesia. Kewenangan kebijakan dan peraturan dimulai dengan adanya UU No. 32 Tahun 2004 tentang otonomi daerah, saat ini sudah diterapkan oleh setiap pemerintah yang berada di daerah untuk mengembangkan, menata, memajukan daerah-daerahnya. Perkembangan sistem pemerintahan untuk menata daerahnya sering kali dipengaruhi oleh aspek kegiatan organisasi terhadap kebutuhan masyarakat untuk memenuhi kehidupannya. Misalkan Kabupaten Subang untuk menuju kota yang berkembang menjadi kota yang bersih, bermartabat, indah, aman, dan tertib harus mengeluarkan suatu kebijakan publik demi kepentingan publik. Untuk menjadikan tatanan Kabupaten Subang menjadi lebih bersih, bermartabat, indah, aman dan tertib, 
Pemerintah Daerah Kabupaten Subang mengeluarkan kebijakan publik dalam Peraturan Daerah Kabupaten Subang Nomor 13 Tahun 2006 Tentang Ketertiban, Kebersihan dan Keindahan.

Peraturan Daerah Kabupaten Subang Nomor 13 Tahun 2006 Tentang Ketertiban,

Kebersihan dan Keindahan, merupakan suatu kebijakan publik yang harus dipatuhi masyarakat dan ditegakkan oleh suatu organisasi yaitu Satuan Polisi Pamong Praja untuk melaksanakan dan menegakan peraturan daerah tersebut. Proses pelaksanaan implementasi kebijakan dalam penegakan peraturan daerah itu akan memberikan suatu interaksi timbal balik antara kinerja pegawai Satuan Polisi Pamong Praja dengan kelompok sasarannya. Kinerja pegawai Satuan Polisi Pamong Praja mempunyai peran sangat penting kepada masyarakat yang mangganggu ketertiban, kebersihan dan keindahan kota, maka dari itu kinerja dari satuan polisi pamong praja dalam penegakan peraturan daerah harus ditingkatan yang sesuai dengan norma dan moral yang berlaku pada setiap tatanan sosial masyarakat. Mengingat pentingnya kebijakan publik itu untuk menuju pemerintah daerah yang tertib, bersih, indah, kinerja pegawai satuan polisi pamong di Kabupaten Subang dituntut untuk memberikan suatu dampak positif dalam penegakan setiap peraturan daerah yang sudah ditetapkan sebelumnya.

Peranan kinerja pegawai satuan polisi pamong praja yang ada di Kabupaten Subang sangat penting dalam penegakan peraturan daerah. Namun sangat disayangkan kinerja pegawai Satuan Polisi Pamong Praja mengalami kendala dan hambatan sering terhimpit dalam berbagai macam permasalahan yang ditimbulkan akibat dari pelaksanaan implementasi kebijakan terutama antara kebutuhan hidup masyarakat untuk memenunhi kebutuhannya, tujuan individual dan tujuan organisasi itu sendiri.

Kinerja pegawai Satuan Polisi Pamong Praja itu harus siap untuk menerima segala resiko dan tanggungjawab yang dihadapinya dalam pelaksanaan implementasi kebijakan peraturan pemerintahan daerah tersebut. Kinerja pegawai yang dimaksud berkaitan dengan hasil-hasil kerja agar pekerjaan yang dilakukan dapat dicapai dengan optimal dan memenuhi standar yang telah ditetapkan organisasi.

Peranan kinerja pegawai merupakan salah satu alat untuk mengukur keberhasilan yang diperoleh organisasi dalam pencapaian tujuannya. Suatu kinerja yang diberlakukan oleh suatu organisasi bersandar pada aturan yang diterapkan oleh instansi tersebut, sehingga dalam realisasinya dapat dilakukan oleh anggota organisasi atau pegawai akan mampu untuk bekerja secara semaksimal serta menghidari dari penilaian subjektif yang tidak semestinya. Kinerja pegawai akan berjalan dengan baik atau organisasi itu berjalan lancar apa bila implementasi kebijakan itu tepat kearah sasaran kelompok masyarakatnya.

Berdasarkan hasil penelitian bahwa diketahui kinerja pegawai di Satuan Polisi Pamong Praja di kota Subang masih rendah, dengan indikator sebagai berikut :

1. Kualitas pegawai Satuan Polisi Pamong Praja belum sepenuhnya dilaksanakan. Terbukti penertiban pedagang kaki lima seharusnya satu hari dapat ditertibkan ternyata baru bisa ditertibkan selama dua hari.

2. Tingkat kuantitas pegawai Satuan Polisi Pamong Praja belum sepenuhnya dilaksanakan dalam menertiban pedagang kaki lima di Kota Subang. Terbukti dari 
Lima Puluh Tiga lapak para pedagang kaki lima yang ada ditempat - tempat trotoar / fasilitas umum ternyata masih adanya Dua Puluh Tujuh lapak pedagang kaki lima yang belum ditertibkan dan sering terjadinya bongkar pasang lapak pedagang kaki lima.

3. Keandalan dan sikap pegawai Satuan Polisi Pamong Praja dalam melaksanakan penertiban pedagang kaki lima di Kota Subang belum sepenuhnya dilaksanakan.

Ini terbukti Tiga kali terjadinya keributan antara pedagang dan pegawai Satuan Polisi Pamong Praja dalam penertiban / pembersihan lapak pedagang kaki lima.

Peneliti mengemukakan Dengan kata lain bahwa Kinerja pegawai tersebut masih rendah diduga disebabkan oleh implementasi kebijakan yang belum dilaksanakan secara sepenuhnya. Kinerja pegawai di Satuan Polisi Pamong Praja mengalami kendala, kesulitan, melaksanakan tugas, fungsi dan tanggungjawab di dalam penegakan implementasi kebijakan atau peraturan pemerintah daerah itu sehingga perlu dicarikan pemecahan masalahnya.

\section{B. Identifikasi masalah}

Berdasarkan latar belakang penelitian yang penulis uraikan, maka penulis mengindentifikasikan masalah tersebut sebagai berikut :

1. Berapa besar pengaruh implementasi kebijakan terhadap kinerja pegawai di Kantor Satuan Polisi Pamong Praja Kabupaten Subang ?.

2. Berapa besar pengaruh implementasi kebijakan melalui faktor Standar dan Sasaran Kebijakan, Sumber daya, Karakteristik organisasi pelaksana, Komunikasi antar organisasi pelaksana dan kegiatan-kegiatan pelaksanaan, Sikap para pelaksana, Lingkungan sosial ekonomi dan politik, terhadap kinerja pegawai di Kantor Satuan Polisi Pamong Praja Kabupaten Subang?.

\section{Tujuan penelitian}

Tujuan penelitian ini adalah sebagai berikut :

1. Menganalisis besarnya pengaruh implementasi kebijakan terhadap kinerja pegawai di Kantor Satuan Polisi Pamong Praja Kabupaten Subang.

2. Mengembangkan konsep implementasi kebijakan konsep kinerja pegawai di Kantor Satuan Polisi Pamong Praja Kabupaten Subang.

3. Menerapkan secara teoritis konsep implementasi kebijakan untuk memecahkan masalah kinerja pegawai di Kantor Satuan Polisi Pamong Praja Kabupaten Subang.

\section{Kegunaan penelitian}

Kegunaan penelitian ini adalah sebagai berikut :

1. Secara teoritis, hasil penelitian ini dapat berguna sebagai bahan pemikiran selanjutnya, dan untuk perkembangan ilmu pengetahuan umumnya, khususnya kajian disiplin ilmu administrasi yang berkaitan dengan implementasi kebijakan dan kinerja pegawai. 
2. Secara Praktis, diharapkan dapat memberikan kontribusi pemikiran untuk menjadi bahan alternatif pemikiran atau pertimbangan sebagai masukan bagi Kantor Satuan Polisi Pamong Praja Kabupaten Subang yang berkaitan dengan Pengaruh Implementasi Kabijakan dan Kinerja Pegawai.

\section{E. Kerangka Teoritis}

Implementasi kebijakan menurut Dunn (2000:132),

mengemukakan implementasi kebijakan yaitu adalah : "Pelaksanaan

pengendalian aksi-aksi kebijakan di dalam kurun waktu tertentu". implementasi

kebijakan merupakan aktifitas praktis yang mengarah pada pemilihan tindakan dan pengamatan sampai selesainya waktu pelaksanaan kebijakan yang bersangkutan. Implementasi kebijakan dibedakan dari formulasi kebijakan yang dapat dipandang sebagai tahapan yang bersifat teoritis. Implementasi kebijakan Publik merupakan proses kegiatan administratif yang dilakukan setelah kebijakan ditetapkan/disetujui.

Implementasi kebijakan sangat menentukan apakah organisasi akan berhasil atau gagal untuk mencapai tujuan sasaran yang telah digariskan dalam kebijakan tersebut sebelumnya. Oleh karena itu implementasi kebijakan berkaitan erat dengan waktu tertetnu dalam pelaksanaanya, dengan kata lain adanya target yang diarahkan untuk dilaksanakan.

Proses implementasi suatu kebijakan dibutuhkan adanya komponen implementasi kebijakan yaitu unsur pelaksana, program dan kelompok sasaran. Unsur pelaksana adalah orang-orang yang berkewajiban untuk melakukan tindakan dan menggunakan saran bagi tercapainya tujuan suatu kebijakan, yang dapat berbentuk organisasi pemerintah. Pihak yang terutama mempunyai kewajiban untuk melaksanakan kebijakan Publik adalah unit-unit administratif atau unit-unit birokratik. Unit-unit administratif atau unit-unit birokratik ini berfungsi sebagai wahana melalui dan dalam hal mana berbagai kegiatan administratif yang bertalian dengan proses kebijakan Publik dilakukan. Dalam implementasi kebijakan ia memiliki diskresi menganai intrumen apa yang paling tepat untuk digunakan. Berdasarkan otoritas dan kapasitas administratif yang dimilikinya ia melakukan berbagai tindakan, mulai dari penentuan tujuan dan sasaran orgnisasional, analisis serta permusan kebijakan dan strategi organisasi, pengambilan keputusan, perencanaan, penyusunan program, pengoranisasian, penggerakan manusia, pelaksanaan kegiatan operasional, pengawasan dan penilaian.

Program merupakan rencana yang bersifat komprehensif yang sudah menggambarkan sumber daya yang akan digunakan dan terpadu dalam satu kesatuan. Program tersebut menggambarkan sasaran, kebijakan, prosedeur, metoda, standar dan budget. Isi program harus menggambarkan volume (bobot) pekerjaan dan sumber dayanya, isi program harus jelas dan dapat dipahami dengan mudah oleh pelaksana atau dengan kata lain program dapat menggambarkan atau mencerminkan secara menyeruh mengenai arah, strategi dan sasaran yang ditempuh oleh setiap unit administratif dalam memecahkan masalah-masalah yang berkembang serta tujuantujuan dan sasaran-sasaran yang hendak dicapai. 
Kelompok sasaran (target group), yaitu sekelompok orang atau organisasi dalam masyarakat yang akan meneriman barang dan jasa atau yang akan dipengaruhi perilakunya oleh kebijakan. Dengan begitu, mereka dapat mengetahui hak-hak yang akan mereka terima dan kewajiban yang semestinya dilakukan. Dalam hal ini faktorfaktor yang mempengaruhi terhadap kebijakan menurut Van Meter dan Van Horn dalam Tachjan (2008:39-40), yaitu sebagai berikut :

1. Standar dan sasaran kebijakan, standar dan sasaran kebijakan pada dasarnya adalah apa yang hendak dicapai oleh program atau kebijakan, baik yang berwujud oleh program atau kebijakan, baik yang berwujud maupun tidak, jangka pendek, menengah, atau panjang. Kejelasan dan sasaran kebijakan harus dapat dilihat secara spesifik sehingga di akhir program dapat diketahui keberhasilan atau kegagalan dari kebijakan atau program yang dijalankan.

2. Sumber daya menunjukan lepada seberapa besar dukungan dan sumber daya manusia untuk melaksanakan program atau kebijakan. Hal sulit yang terjadi adalah berapa nilai sumber daya (baik finansial maupun manusia) untuk menghasilkan implementasi kebijakan dengan kinerja baik. Evaluasi program atau kebijakan seharusnya dapat menjelaskan nilai yang efesien.

3. Karakteristik organisasi pelaksana, menunjuk seberapa besar daya dukung struktur organisasi/ struktur birokrasi, nilai-nilai yang berkembang, hubungan dan komunikasi yang terjadi di internal birokrasi.

4. Komunikasi antar organisasi pelaksana dan kegiatan-kegiatan pelaksanaan, menunjukan kepada mekanisme prosedur yang dirancangkan untuk mencapai sasaran dan tujuan program. Komunikasi ini harus ditetapkan sebagai acuan, misalnya: seberapa sering rapat rutin akan diadakan, tempat dan waktu. Komunikasi antar organisasi juga menunjuk adanya tuntutan saling dukung antar institusi yang berkaitan dengan program atau kebijakan dan kelompok sasaran mampu memahami dan bertanggung jawab atas program yang dijalankan dalam pelaksanaan kegiatan-kegiatan.

5. Sikap para pelaksana, menunjuk bahwa sikap para pelaksana menjadi variabel penting dalam implementasi kebijakan. Seberapa demokkratis, antusias, dan responsif terhadap kelompok sasaran dan lingkungan beberapa yang dapat ditunjuk sebagai bagian dari sikap pelaksana ini.

6. Lingkungan sosial, ekonomi dan politik, menunjuk bahwa lingkungan dalam ranah implementasi dapat mempengaruhi kesuksesan implementasi kebijakan itu sendiri.

Penulis telah menjelaskan diatas mengenai teori implementasi kebijakan dan alat analisis atau alat ukur implementasi kebijakan yaitu faktor-faktor yang mempengaruhi kebijakan publik, selanjutnya penulis akan mengemukakan tentang pengertian kinerja pegawai menurut Mangkunegara (2003:67), yaitu mengemukakan bahwa kinerja adalah 
"Kinerja merupakan hasil kerja secara kualitas dan kuantitas yang dicapai oleh seseorang dalam melaksanakan fungsinya sesuai dengan tanggung jawab yang diberikan kepadanya".

Kinerja pegawai dalam melaksanakan tugasnya untuk mencapai sasaran dan waktu yang telah ditetapkan tanpa menghiraukan jumlah biaya, tenaga dan alat-alat yang telah dipergunakan sesuai yang dimilikinya sehingga untuk mendapatkan kejelasan pelaksanaan implementasi kebijakan tersebut.

Pengukuran kinerja merupakan salah satu faktor penting dalam meningkatkan daya saing sebuah organisasi. Rancangan sistem pengukuran kinerja yang akurat dan kontekstual merupakan jembatan emas kearah mana keunggulan sebuah organisasi akan dibawa. Sehubungan dalam hal tersebut Menurut Mangkunegara (2003:75), mendefinisikan kedalam empat dimensi kinerja pegawai, yaitu :

1. Kualitas Kerja yang dimaksud meliputi ketepatan, ketelitian, keterampilan serta keberhasilan.

2. Kuantitas kerja yang meliputi Output rutin serta output non rutin atau ekstra.

3. Keandalan atau dapat tidaknya diandalkan yakni dapat tidaknya mengiktui instruksi, kemampuan, inisiatif, kehati-hatian serta kerajinan,

4. Sikap yang meliputi sikap terhadap perusahaan, pegawai lain, terhadap pekerjaan serta kerjasama.

Apabila pengertian implementasi kebijakan dihubungkan dengan kinerja pegawai maka dapat diperoleh kesimpulan yang menjelaskan implementasi kebijakan memiliki pengaruh yang sangat besar terhadap kinerja pegawai. Sebagaimana dikemukan oleh pendapat menurut Van Meter dan Van Horn dalam Wahab (2004:7879), yaitu :

Bahwa perbedaan-perbedaan dalam proses implementasi akan dipengaruhi oleh sifat kebijakan yang akan dilaksanakan. Selanjutnya mereka menawarkan suatu pendekatan yang mencoba untuk menghubungkan antara isu kebijakan dengan implementasi dan suatu model konseptual yang mempertalikan kebijakan dengan performance.

Bertitik tolak pada kerangka pemikiran di atas, maka dapat digambarkan paradigma pemikiran penelitian dibawah ini sebagai berikut :

\section{Implementasi Kebijakan}

dalam Tachjan, 2008(Van Meter dan Van :39Horn -40)

1. Standar dan Sasaran Kebijakan

2. Sumber daya

3. Karakteristik organisasi pelaksana
Kinerja Pegawai (Mangkunegara, 2003:75)

1. Kualitas Kerja

2. Kuantitas Kerja

3. Keandalan

4. Sikap 


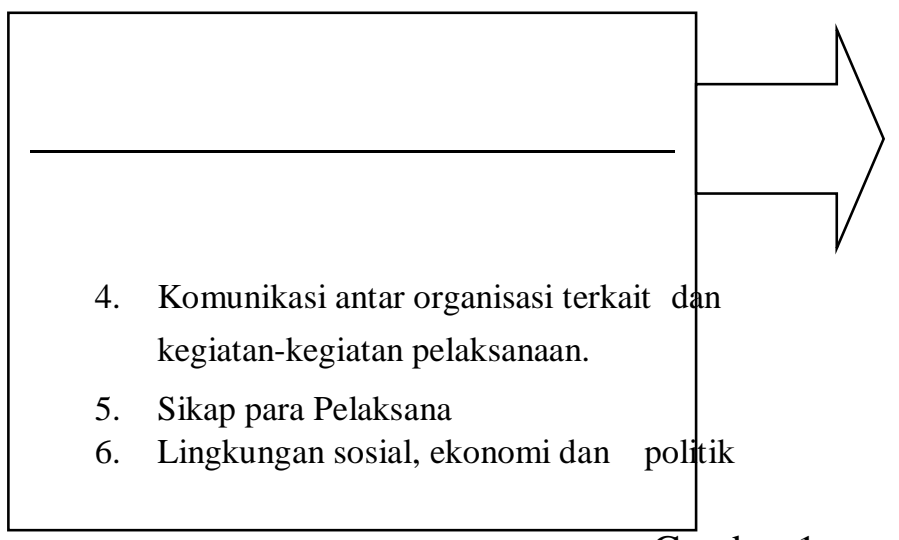

Gambar 1

Paradigma Kerangka Pemikiran

\section{F. Hipotesis}

Berdasarkan kerangka pemikiran di atas, maka peneliti merumuskan hipotesis sebagai berikut :

1. Implementasi kebijakan besar pengaruhnya terhadap kinerja pegawai pada Kantor Satuan Polisi Pamong Praja Kabupaten Subang.

2. Implementasi kebijakan melalui faktor Standar dan Sasaran Kebijakan, Sumber daya, Karakteristik organisasi pelaksana, Komunikasi antar organisasi pelaksana dan kegiatan-kegiatan pelaksanaan, Sikap para pelaksana, Lingkungan sosial ekonomi dan politik, besar pengaruhnya terhadap kinerja pegawai pada Kantor Satuan Polisi Pamong Praja Kabupaten Subang.

\section{G. Metode penelitian}

Metode penelitian yang digunakan oleh penulis adalah survei. Penelitian survei pada umumnya dilakukan untuk mengambil suatu generalisasi dari pengamatan. Agar generalisasi yang dilakukan mendapatkan hasil yang akurat, maka diperlukan sampel yang resprensif dari suatu populasi. Adapun tujuan dari metode survei adalah untuk mengumpulkan informasi faktual secara detail, mengindentifikasi masalah dan justifikasi kondisi saat ini serta membuat perbandingan dan evaluasi/kesimpulannya.

Instrumen yang digunakan adalah angket, maksudnya dalam survei ini informasi dikumpulkan dari responden dengan menggunakan angket. Umumnya, pengertian survei dibatasi pada penelitian yang datanya dikumpulkan dari sampel atas populasi untuk mewakili populasi.

Analisis dalam pengolahan data melalui analisis jalur (path analysis) yaitu melihat besarnya pengaruh dari variabel implementasi kebijakan terhadap kinerja pegawai di Kantor Satuan Polisi Pamong Praja Kabupaten Subang.

Pendekatan penelitian ini adalah deskriritif analisis yang menggambarkan masing-masing variabel yang menguji kedua variabel melalui pendekatan kuantitatif.

\section{H. Desain penelitian}

Desain penelitian menggambarkan hubungan terstruktur variabel-variabel secara komprehensif, yaitu hubungan antara variabel bebas (X) Implementasi Kebijakan dengan variabel terikat (Y) Kinerja pegawai, agar hasil penelitian dapat memberikan jawaban atas hipotesis penelitian. 
Desain penelitian secara konseptual yang akan digunakan oleh peneliti dapat digambarkan sebagai berikut :

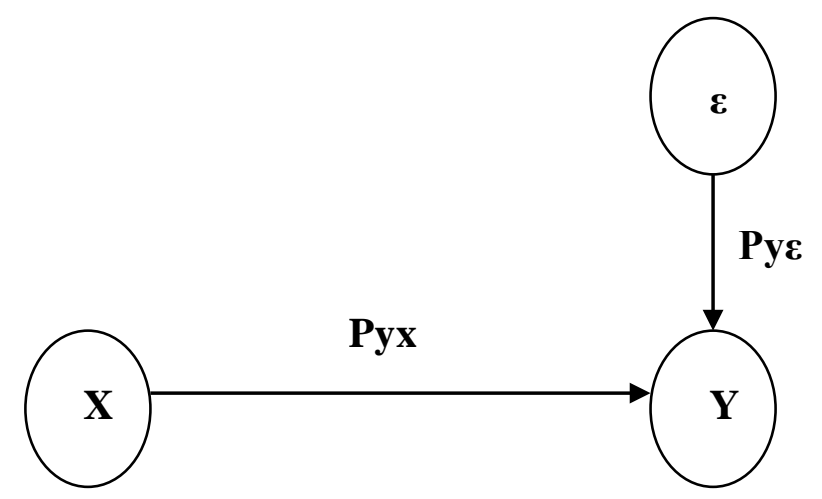

Gambar 2

Desain Variabel Penelitian

Keterangan :

$\mathrm{X}=$ Variabel Implementasi

$\mathrm{Y}=$ Variabel Kinerja Pegawai Pyx =

Koefesien X dan Y

$\varepsilon \quad=$ Variabel yang mempengaruhi di luar variabel yang diteliti Py $\varepsilon$

$=$ Koefesien variabel residu / epsilon

\section{Analisis dan pembahasan}

Peneliti menyebarkan angket kepada sejumlah pegawai yang berada di Kantor Satuan Polisi Pamong Praja Kabupaten Subang dengan jumlah sebanyak 93 Orang responden dan total pernyataan untuk setiap angketnya yaitu sejumlah 58 item pernyataan harus diisi oleh setiap responden dengan 5 alternatif jawaban setiap itemnya dengan menggunakan skala likert yang terdiri dari pertayaan positif dan negatif.

Berdasarkan hipotesis yang telah dikemukan oleh peneliti, maka struktur variabel $\mathrm{X}$ ke $\mathrm{Y}$ diuji Implementasi kebijakan besar pengaruhnya terhadap kinerja pegawai pada Kantor Satuan Polisi Pamong Praja Kabupaten Subang, dengan menggunakan metode analisisnya yaitu Path Analysis. Adapun hasil Path Analysis dijelaskan sebagai berikut:

Tabel 2

Koefisien Korelasi Multipel

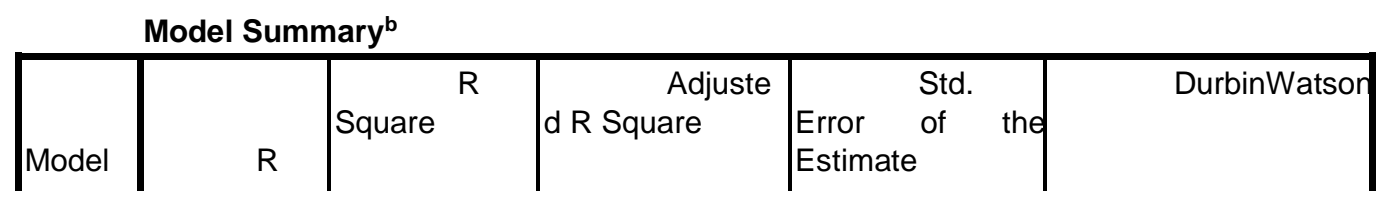




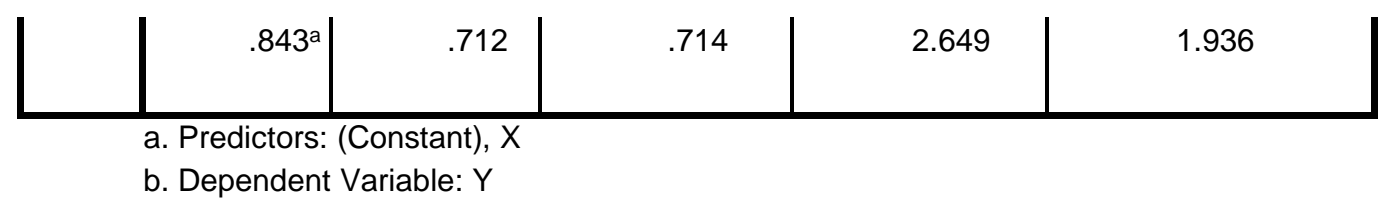

Tabel 2 menunjukkan nilai koefisien determinasi $\left(\mathrm{R}^{2}\right)$ sebesar 0,712 berarti bahwa variabilitas kinerja pegawai dapat diterangkan oleh variabel bebas dalam hal ini implementasi kebijakan, yang juga dapat diartikan bahwa terdapat pengaruh implementasi kebijakan terhadap kinerja pegawai sebesar koefisien determinasi $\left(\mathrm{R}^{2}=\right.$ $71,2 \%$ ) atau $71,2 \%$ ini juga dapat diartikan bahwa pengaruh variabel-variabel di luar model yaitu sebesar $\square_{\mathrm{y}}=1-\mathrm{R}^{2}=0,288$ (error). Besarnya koefisien jalur untuk masingmasing variabel adalah sebagai berikut :

Tabel 2.1

Nilai-nilai Standardized Coefficients untuk Koefisien Jalur

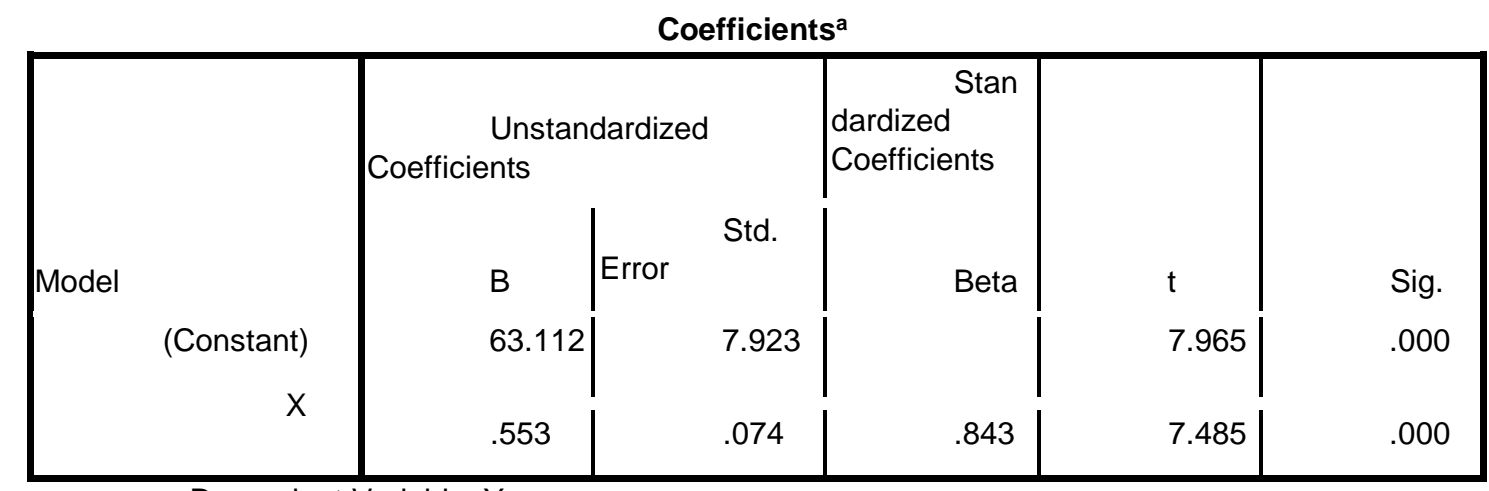

a. Dependent Variable: $Y$

Tabel 2.1 menjelaskan nilai standaridized cofficients atau koefisien jalur dari variabel implementasi kebijakan terhadap variabel kinerja pegawai, yaitu koefisien jalur dari $\mathrm{X}$ ke $\mathrm{Y}=$. Jika dibandingkan nilai koefisien $\rho \mathrm{YX}=0,716$ dengan sig. $=0,000$ dan $\alpha=0.05$, maka sig. $=0,000<\alpha=0.05$ menunjukkan bahwa pengaruh implementasi kebijakan terhadap kinerja adalah signifikan. 
Hasil pengolahan data dapat dibuat dalam bentuk diagram jalur dan persamaan struktural dengan menyertakan koefisien estimasi hasil pengolahan data, maka persamaan strukturalnya adalah:

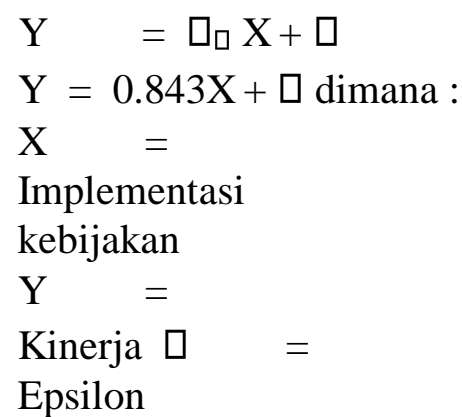

Mengacu pada tabel koefisien korelasi multiple untuk struktur yang diuji menunjukkan nilai koefisien determinasi multipel dan seluruh variabel eksogenus yang diuji adalah sebesar $\mathrm{R}^{2}=71,2 \%$. Nilai determinasi multipel ini merupakan kuadrat dari nilai koefisien korelasi multipel $\mathrm{R}=0,843$. Nilai $\mathrm{R}^{2}$ ini menunjukkan bahwa derajat pengaruh implementsi kebijakan sangat erat jika dibandingkan dengan variabel lain yang tidak diteliti. Hasil perhitungan tersebut dapat dilihat pada gambar berikut ini:

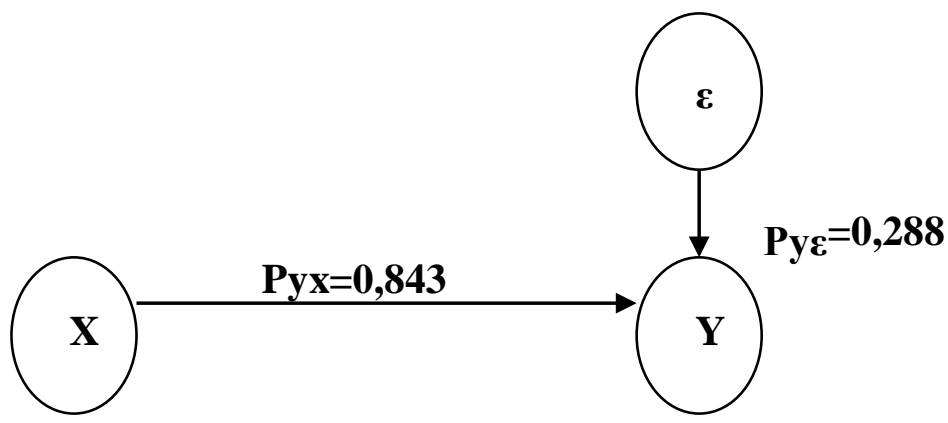

Gambar 3

Struktur Koefisien Jalur Variabel X ke Y

Berdasarkan nilai-nilai koefisien jalur tersebut, selanjutnya dapat dihitung bahwa besarnya pengaruh dari variabel $\mathrm{X}$ ke $\mathrm{Y}$ adalah 0.712 yang merupakan kuadrat dari nilai koefisien $\mathrm{R}=0.843$, sedangkan besarnya pengaruh variabel lain yang tidak diteliti adalah sebesar 0.288 , untuk lebih jelasnya dapat dilihat pada gambar berikut ini 


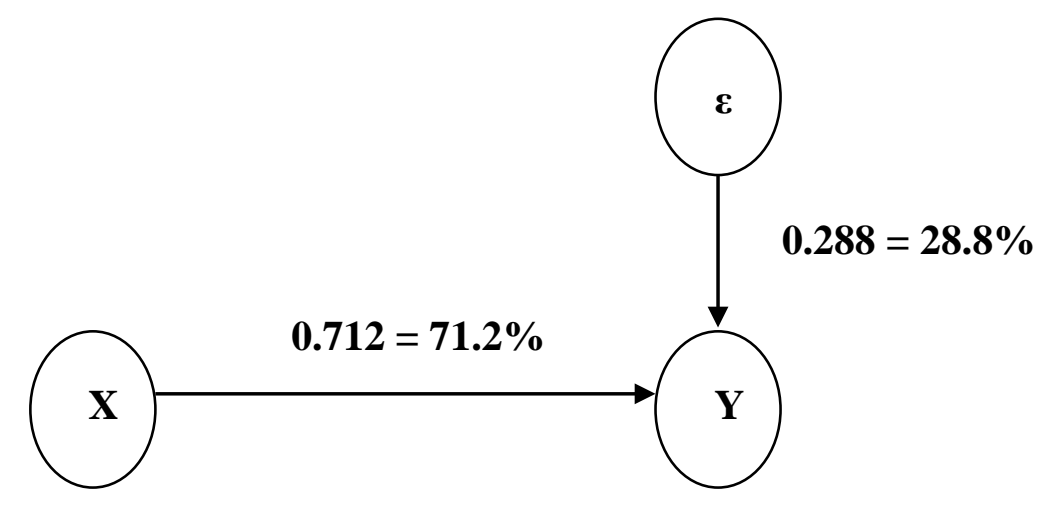

Gambar 3.1

Besarnya Pengaruh Variabel X ke Y

Peneliti kemudian menguji Implementasi kebijakan melalui faktor Standar dan Sasaran Kebijakan, faktor Sumber daya, faktor Karakteristik organisasi pelaksana, faktor Komunikasi antar organisasi pelaksana dan kegiatan-kegiatan pelaksanaan, faktor Sikap para pelaksana, faktor Lingkungan sosial ekonomi dan politik, besar pengaruhnya terhadap kinerja pegawai pada Kantor Satuan Polisi Pamong Praja Kabupaten Subang.

Berdasarkan hasil perhitungan Sub Struktur X1, X2, X3, X4, X5, X6 ke Y dengan menggunakan metode Path Analysis dapat digambarkan sebagai berikut : 


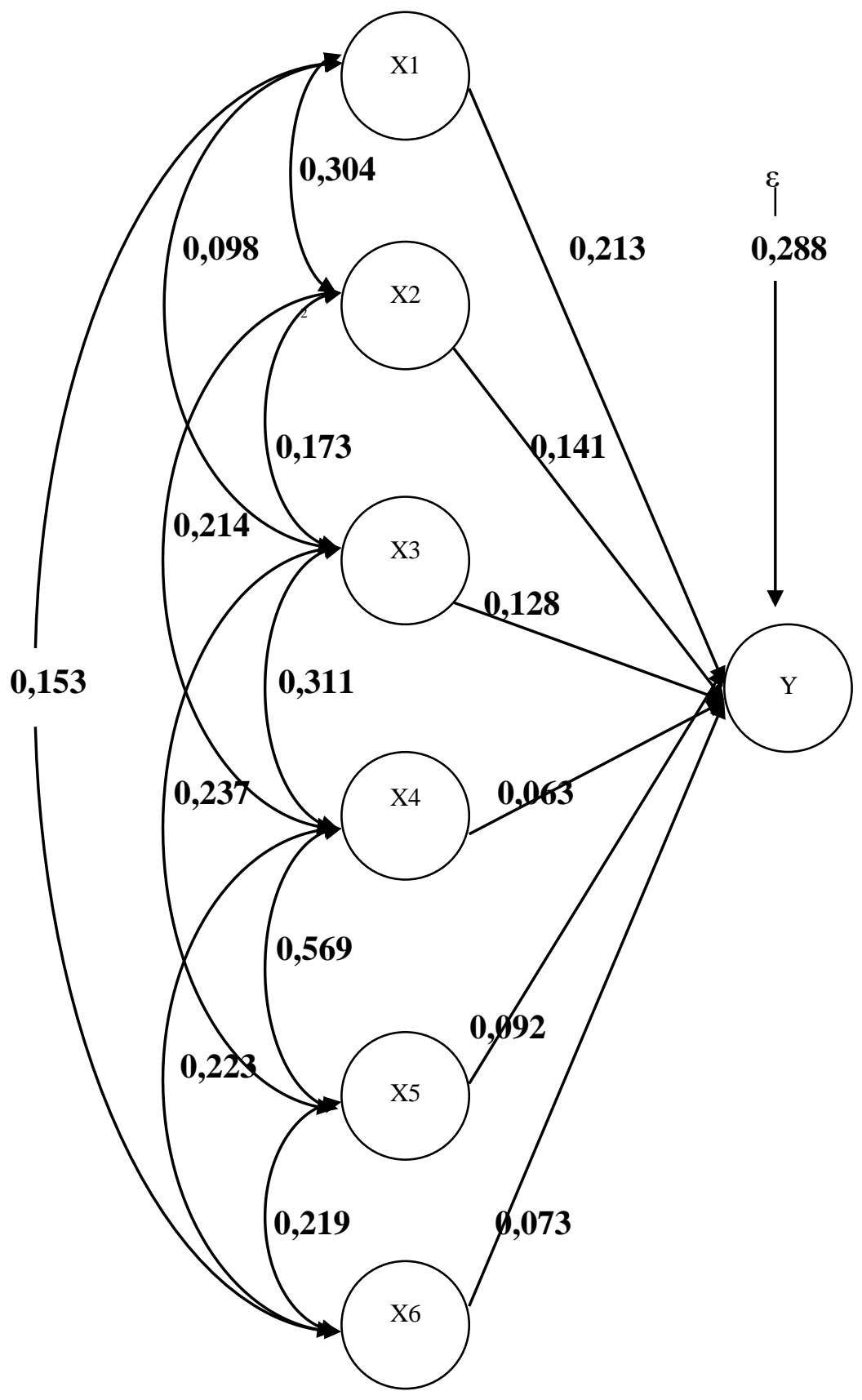

Gambar 3.2

Hasil Path Analysis Sub Struktur X1, X2, X3, X4, X5, X6 ke Y Pembahasan secara simultan pengaruh implementasi kebijakan terhadap kinerja pegawai di kantor satuan polisi pamong praja kebaupaten subang

Berdasarkan hasil penelitian dapat diperoleh gambaran bahwa secara simultan bentuk pengaruh antar variabel telah sesuai dengan hipotesis yang dikemukakan. 
Implementasi kebijakan yang diukur dengan Standar dan Sasaran Kebijakan, Sumber daya, Karakteristik organisasi pelaksana, Komunikasi antar organisasi pelaksana dan kegiatan-kegiatan pelaksanaan, Sikap para pelaksana, Lingkungan sosial ekonomi dan politik berpengaruh terhadap kinerja pegawai pada satuan polisi pamong praja kabupaten subang. Besarnya pengaruh implementasi kebijakan tersebut adalah sebesar $71.2 \%$, selebihnya dipengaruhi oleh faktor yang lain.

Peneliti mengungkapkan bawha implementasi kebijakan di lingkungan kantor satuan polisi pamong praja kabupaten subang dipandang sebagai faktor pendukung guna meningkatkan kinerja pegawai. Hal ini didasari bahwa lahirnya suatu kebijakan merupakan suatu arahan tindakan nyata yang harus dilakukan pemerintah dan mempunyai tujuan untuk mengatasi masalah atau permasalahan yang ada di dalam masyarakat maupun organisasi. Sementara implementasi kebijakan merupakan pelaksana dan pengendalian arah tindakan untuk pencapaian tujuan.

Implementasi kebijakan yang akan dilaksanakan oleh satuan polisi pamong praja belum dapat sepenuhnya dilaksanakan karena disebabkan ada beberapa faktorfaktor yang belum terpenuhi, seperti satuan polisi pamong praja komunikasi antar organisasi pelaksana dan kegiatan-kegiatan pelaksana, sikap para pelaksana, disertai dengan lingkungan sosial, ekonomi dan politik.

Peneliti membandingkan dengan penelitian-penelitian sebelumnya yang membahas tentang pengaruh implementasi kebijakan terhadap kinerja pegawai, bahwa telah terbukti secara empiris bahwa ke enamt faktor yaitu Standar dan Sasaran Kebijakan, Sumber daya, Karakteristik organisasi pelaksana, Komunikasi antar organisasi pelaksana dan kegiatan-kegiatan pelaksanaan, Sikap para pelaksana, Lingkungan sosial ekonomi dan politik berpengaruh terhadap kinerja pegawai dan juga mempunyai pengaruh yang signifikan terhadap peningkatan kinerja pegawai.

Teori-teori yang digunakan oleh peneliti dalam penelitian ini pun hasilnya tidak jauh jika dibandingkan dengan realita di lapangan. Terbukti bahwa antara kebijakan dengan kinerja pegawai itu saling berkaitan dan implementasi kebijakan terbukti secara empiris mempengaruhi kinerja pegawai di suatu organisasi atau instansi.

Hasil temuan penelitian yang berkaitan dengan rendahnya kinerja pegawai, kantor satuan polisi pamong praja Kabupaten Subang. Ditunjukan oleh kualitas kerja, kuantitas kerja, keandalan dan sikap. Bahwa hasil penelitian faktor implementasi kebijakan di lingkungan kantor satuan polisi pamong praja kabupaten subang dipandang sebagai salah satu faktor pendukung guna meningkatkan kinerja pegawai. Dari temuan yang ada dapat terlihat bahwa implementasi kebijakan penertiban pedagang kaki lima tidak dapat diimplementasikan sepenuhnya karena belum terpenuhinya beberapa faktorfaktor implementasi kebijakan. Hal tersebut mempengaruhi terhadap kinerja pegawai di kantor satuan polisi pamong praja kabupaten subang. Sesuai hasil wawancara peneliti dengan kepala satuan polisi pamong praja kabupaten subang, peneliti menimpulkan, bahwa dalam upaya untuk memeprbaiki permasalahan tersebut dan untuk mengatasinya sekaligus meningkatkan kinerja pegawai satuan polisi pamong praja, maka akan diselenggarakannya pendidikan dan pelatihan, untuk meningkatkan sumber daya manusia dengan memperbolehkan dan mewajibkan para pegawainya untuk melanjutkan 
kejenjang yang lebih tinggi lagi dalam bidang pendidikannya, penempatan para pegawai yang sesuai dengan fungsi, tugas dan tanggungjawabnya serta menjalin hubungan dan komunikasi dengan instansi/organisasi dengan baik sehingga dalam proses pelaksanan kebijakan dari setiap program pelaksanaan kebijakan dapat efesien dan efektif.

\section{Pembahasan secara parsial implementasi kebijakan terhadap kinerja pegawai 1. Faktor Standar dan Sasaran Kebijakan}

Hipotesis yang diajukan peneliti bahwa implementasi kebijakan diukur melalui faktor standar dan sasaran kebijakan (X1) besarnya pengaruh terhadap kinerja pegawai (Y). Hasil pengolahan data menunjukan bahwa faktor standar dan sasaran kebijakan berpengaruh signifikan terhadap kinerja pegawai adalah sebesar 0,213 atau 21,3\%.

Faktor standar dan sasaran kebijakan menunjukan peranan penting sebagai acuan agar pelaksanaan kebijakan mengetahui persis apa yang akan mereka kerjakan. Faktor standar dan sasaran kebijakan dapat diartikan bahwa tingkat kemajemukan dari kelompok sasaran, ini berarti suatu program akan relatif mudah diimplementasikan apabila kelompok sasarannya homogen. Sebaliknya, apa bila kelompok sasaran heterogen, maka implementasi program akan relatif sulit, karena tingkat pemahaman setiap anggota kelompok sasaran terhadap program relatif berbeda.

Kinerja Satuan Polisi Pamong Praja, sudah melakukan perannnya untuk melaksanakan programnya yaitu penertiban pedagang kaki lima dengan secara efektif karena standar dan sasaran kebijakannya sudah jelas dan terukur sehingga dapat direalisir.

\section{Faktor Sumber daya}

Hipotesis yang diajukan peneliti bahwa implementasi kebijakan diukur melalui faktor sumber daya (X2) besarnya pengaruh terhadap kinerja pegawai (Y). Hasil pengolahan data menunjukan bahwa faktor sumber daya berpengaruh signifikan terhadap kinerja pegawai adalah sebesar 0,141 atau 14,1\%.

Faktor sumber daya merupakan faktor penting dalam proses pelaksanaan suatu implementasi kebijakan, implementasi kebijakan perlu dukungan sumber daya baik sumber daya manusia maupun sumber daya non-manusia atau sumber daya finansial. Besarnya alokasi sumber daya finansial terhadap kebijakan merupakan faktor kursial untuk sebuah program sosial. Setiap program juga membutuhkan atau memerlukan dukungan dari setiap sumber daya manusia untuk melakukan pekerjaan-pekerjaan administrasi dan teknis, serta memonitor program, yang semuanya itu perlu biaya. Namun dalam konteks pelaksanaan implementasi kebijakan yang dilaksanakan oleh Satuan Polisi Pamong Praja Kabupaten Subang, sudah sepenuhnya dilaksanakan dengan efektif. Akan tetapi faktor sumber daya ini belum bisa memeberikan dampak yang positif dalam pencapaian pelaksanaan tujuan implementasi kebijakan. Disebabkan ada beberapa pemasalahan yang menghempitnya dalam proses pelaksanaan kebijakan terutama sumber daya manusia yang belum optimal atau kurang handal dari beberapa pegawai satuan polisi pamong itu sendiri yang mempunyai latar pendidikan yang berbeda-beda, serta sumber daya finansial benarbenar belum memadai demi 
terselengarakannya suatu program pelaksanana implementasi kebijakan yaitu dalam hal penertiban padagang kaki lima. Seiring dengan penertiban pedagang kaki lima ini, biaya finansial yang sering dikeluar oleh satuan polisi pamong praja kabupaten tidak hanya sedikit melainkan mengeluarkan anggaran begitu besar. Ada beberapa program implementasi kebijakan yang belum dapat dilaksanakan dikarena oleh keterbatasan sumber daya manusia, dan hal yang paling mencolok adalah sumber daya finansial atau anggaran, sehingga satuan polisi pamong praja harus bisa membuat skala prioritas dalam pelaksanaan implementasi kebijakan.

\section{Faktor Karakteristik organisasi pelaksana}

Hipotesis yang diajukan peneliti bahwa implementasi kebijakan diukur melalui faktor Karakteristik organisasi pelaksana (X3) besarnya pengaruh terhadap kinerja pegawai (Y). Hasil pengolahan data menunjukan bahwa faktor Karakteristik organisasi pelaksana berpengaruh signifikan terhadap kinerja pegawai adalah sebesar 0,128 atau $12,8 \%$.

Faktor karakteristik organisasi pelaksana dapat diartikan bahwa untuk mencapai suatu program implementasi kebijakan perlu dukungan stuktur organisasi, hubungan dan komunikasi internal birokrasi yang baik. Sebagaimana mestinya faktor karakteristik organisasi pelaksana ini merupakan faktor yang penting dalam pelaksanakan program implementasi kebijakan. Peranan satuan polisi pamong praja kabupaten subang mempunyai andil hubungan dan komunikasi untuk saling mendukung dalam struktur organisasi dengan struktur organisasi yang lainya dan instansi yang terkait.

Pelaksanaan program implementasi kebijakan dalam hal penertiban pedagang kaki lima yang dilakukan oleh satuan polisi pamong praja kabupaten subang sebelum melaksanakan penertiban pedagang kaki lima selalu berhubungan terelebih dahulu dan berkomunikasi dengan internal birokrasi yang terkait sehingga proses pelaksanaan implementasi kebijakan penertiban pedagang kaki lima dapat dilaksanakan secara efektif. Akan tetapi satuan polisi pamong praja masih mempunyai kesulitan untuk berhubungan dan berkomunikasi internal dengan birokrasi, disebabkan pula dikarenakan ada beberapa struktur organisasi maupun birokrasi yang mempunyai keterkaitan suatu kepentingan individu sebelum mereka melaksanakan tujuan organisasinya.

\section{Faktor Komunikasi antar organisasi pelaksana dan kegiatan-kegiatan pelaksanaan}

Hipotesis yang diajukan peneliti bahwa implementasi kebijakan diukur melalui faktor Komunikasi antar organisasi pelaksana dan kegiatan-kegiatan pelaksanaan (X4) besarnya pengaruh terhadap kinerja pegawai (Y). Hasil pengolahan data menunjukan bahwa faktor Komunikasi antar organisasi pelaksana dan kegiatankegiatan pelaksanaan berpengaruh signifikan terhadap kinerja pegawai adalah sebesar 0,063 atau 6,3\%.

Faktor komunikasi antar organisasi pelaksana dan kegiatan-kegiatan pelaksana merupakan faktor penting yang harus dilaksanakan oleh satuan polisi pamong praja, selain itu juga faktor ini merupakan faktor yang mempunyai dampak dalam pelaksanaan kebijakan, sebab keberhasilan suatu program implementasi kebijakan dengan adanya faktor koordinasi dan kerja sama yang baik antar organisasi maupun satuan polisi 
pamong praja itu sendiri. Namun sangat disayangkan proses koordinasi baik secara vertikal maupun horisontal antar instansi maupun pegawai satuan polisi pamong praja serta kerjasamanya kurang efektif. Akan tetapi selebihnya proses pelaksanaan kebijakan penertiban pedangan kaki lima dengan adanya standar operating prosedur (SOP) dan hanya sebagian kecil saja satuan polisi pamong praja yang belum memahami tentang SOP, tetapi arah dan pencapaian pelaksanaan penertiban yang dilakukan oleh satuan polisi pamong praja kurang dapat dilaksanakan secara optimal. sehingga satuan polisi pamong praja telah menerapkan standar operating prosedur demi mempermudahkan mereka dalam melaksanakan pencapaian tujuan organisasinya walaupun dalam prakteknya dilapangan terkadang beberapa hal yang tidak bisa benar-benar sesuai dengan SOP.

\section{Faktor Sikap para pelaksana}

Hipotesis yang diajukan peneliti bahwa implementasi kebijakan diukur melalui faktor Sikap para pelaksana (X5) besarnya pengaruh terhadap kinerja pegawai (Y). Hasil pengolahan data menunjukan bahwa faktor Sikap para pelaksana berpengaruh signifikan terhadap kinerja pegawai adalah sebesar 0,092 atau 9,2\%.

Faktor sikap para pelaksana harus mempunyai kejelasan dan konsisten aturan yang ada pada para pelaksana, maksudnya adalah tingkat komitmen satuan polisi pamong praja terhadap tujuan kebijakan. Faktor sikap para pelaksana ini merupakan faktor penting sebab mencerminkan bagaimana satuan polisi pamong praja menyingkapi permasalahan yang ada dilapangan dan melaksanakan tugas mereka dalam menertibkan pedagang kaki atau pelaksanaan program implementasi kebijakan yang sedang mereka hadapi.

Faktor sikap para pelaksana telah dilaksanakan disatuan polisi pamong praja, dengan membuat prioritas tujuan dan merealisasikan tujuan dengan mengkaidahkan proses pelaksanaan implementasi kebijakan secara antusias, responsif dan demokrasi. Namun dalam hal demokrasi kurang bisa dilakukan oleh satuan polisi pamong praja dikarenakan demokrasi ini lah yang menghambat proses penertiban pedagang kaki lima atau pelaksanaan implementasi kebijakan yang sedang dilakukan oleh satuan polisi pamong praja. Proses pelaksanaan implementasi kebijakan merupakan hal yang wajib harus ditegaskan dan ditegakan oleh satuan polisi pamong praja.

\section{Faktor Lingkungan sosial, ekonomi, dan politik}

Hipotesis yang diajukan peneliti bahwa implementasi kebijakan diukur melalui faktor Lingkungan sosial, ekonomi, dan politik (X6) besarnya pengaruh terhadap kinerja pegawai (Y). Hasil pengolahan data menunjukan bahwa faktor Lingkungan sosial, ekonomi, dan politik berpengaruh signifikan terhadap kinerja pegawai adalah sebesar 0,073 atau $7,3 \%$

Faktor lingkungan sosial, ekonomi dan politik merupakan faktor penting dalam pelaksanaan implementasi kebijakan. Kinerja satuan polisi pamong praja benar-benar dipengaruhi oleh faktor lingkungan sosial, ekonomi dan politik. Tercapainya pelaksanaan implementasi kebijakan dalam penertiban pedagang kaki lima yang dilakukan oleh satuan polisi pamong praja sudah bisa memberikan arti yang positif bila 
para elit politik dan kelompok-kelompok tertentu saling bila saling memberikan dukungan.

\section{Faktor lain yang mempengaruhi kinerja pegawai diluar variabel implementasi kebijakan}

Adapun faktor lainnya yang disinyalir ikut mempengaruhi sisanya sebesar 28,8\% oleh variabel lain yang tidak diteliti dalam penelitian ini, diantaranya yaitu : Pengawasan, Insentif, Perilaku Organisasi, Kepemimpinan. Peneliti melihat bahwa keempat faktor itu mempunyai potensi dalam mempengaruhi Kinerja Pegawai Di Kantor Satuan Polisi Pamong Praja Kabupaten Subang.

\section{J. Kesimpulan dan Saran-Saran}

Berdasarkan hasil penelitian tentang Pengaruh Implementasi Kebijakan terhadap Kinerja Pegawai Di Kantor Satuan Polisi Pamong Praja Kabupaten Subang, (Studi Implementasi Kebijakan Tentang Peraturan Daerah Kab. Subang No. 13 Tahun 2006 Tentang Ketertiban, Kebersihan, dan Keindahan) yang telah dikemukakan pada deskripsi dan pembahasan, maka secara komprehensif peneliti dapat menyimpulkan hasil penelitian sebagai berikut:

1. Impelementasi kebijakan cukup kuat dan signifikan terhadap kinerja pegawai,

2. Implementasi Kebijakan yang terdiri dari Faktor Standar dan Sasaran Kebijakan menunjukkan pengaruh yang paling besar terhadap kinerja pegawai, selanjutnya diikuti oleh faktor Sumber daya, faktor Karakteristik organisasi pelaksana, faktor Sikap para pelaksana, faktor Lingkungan sosial ekonomi dan politik. Sedangkan pengaruh yang terkecil terhadap kinerja pegawai adalah dari faktor Komunikasi antar organisasi pelaksana dan kegiatan-kegiatan pelaksanaan.

3. Selain Implementasi kebijakan dan kinerja pegawai juga dipengaruhi oleh faktor lain yang tidak diteliti pada penelitian ini.

\section{SARAN}

Berdasarkan temuan penelitian, peneliti dapat menyampaikan saran-saran penelitian yang diharapkan dapat menjadi rekomendasi, baik dalam konteks pengembangan ilmu maupun sebagai kontribusi bagi implementasi kebijakan yang berdampak pada kinerja. Adapun saran yang dimaksud antara lain:

\section{Saran Akademik}

Peneliti/Penulis menyarankan perlu dilakukan penelitian lanjutan tentang fenomena belum sepenuhnya dilaksanakan implementasi kebijakan dan kinerja pegawai, khususnya ditinjau dari perspektif ilmu kebijakan publik. Fenomena tersebut diperkuat oleh adanya faktor lain yang tidak diteliti di luar dari penelitian ini, namun mempengaruhi kinerja pegawai. Temuan ini dapat dijadikan bahan penelitian lanjutan berkaitan dengan pengaruh berbagai faktor terhadap kinerja pegawai.

\section{Saran Praktis}

Perlu adanya pemahaman yang lebih komprehensif tentang implementasi kebijakan, khususnya berkaitan dengan peningkatan faktor Komunikasi antar organisasi 
pelaksana dan kegiatan-kegiatan pelaksanaan. Sehubungan dengan masih lemahnya aspek tersebut dalam mempengaruhi kinerja pegawai, maka perlu adanya pengkajian yaNg lebih mendalam dan fragmentasi. Dengan adanya peningkatan faktor Komunikasi antar organisasi pelaksana dan kegiatan-kegiatan pelaksanaan diharapkan tercapai optimalisasi kinerja pegawai pada Kantor Satuan Polisi Pamong Praja Kab. Subang. Selain itu juga pentingnya membangun sumber daya manusia dengan mengadakan pendidikan dan pelatihan kepada para pegawai satuan polisi pamong praja kab. Subang selain untuk menjadi pegawai yang lebih handal, maka peranan kerjasama dan komunikasi dengan instansi yang lain perlu ditingkatkan serta partisipasi masyarakat perlu dilibatkan dalam pengimplementasian kebijakan ini.

Berkaitan dengan temuan tersebut dipandang layak untuk meningkatkan keefektifan proses implementasi kebijakan agar menjadi semakin lebih optimal yang bertujuan untuk meningkatkan kualitas kinerja dalam rangka menyukseskan penertiban pedagang kaki lima.

\section{Saran Kebijakan}

Faktor Komunikasi antar organisasi pelaksana dan kegiatan-kegiatan pelaksanaan menunjukkan pengaruh yang kecil terhadap kinerja pegawai. Dengan demikian, peningkatan kualitas Komunikasi antar organisasi pelaksana dan kegiatankegiatan pelaksanaan khususnya dalam pelaksanaan Standard Operating Procedure (SOP) selayaknya menjadi prioritas agar kinerja pegawai semakin handal. Peneliti menyarankan harus adanya suatu peraturan yang menjelaskan tentang Standard Operating Procedure (SOP) supaya proses pelaksanaan suatu kebijakan dapat berjalan secara efektif.

\section{DAFTAR PUSTAKA}

Anderson, James E. 1979. Public Policy Making. New York: Holt, Rinehart and Winston.

Dunn, William N. 2000. Pengantar Analisis Kebijakan Publik. (Penerjemah:Muhadjir). Gajah Mada University Press. Yogyakarta.

Dye, Thomas R. 1976. Policy Analsis : What Governments Do, Whya They Do it and What Difference it makes. The University Alabama.

Islamy, M. Irfan. 2000-cetakan kesembilan. Prinsip-prinsip Perumusan Kebijakan Negara. Bumi Aksara. Jakarta.

Keban, Yaremis T. 1995. Indikator Kinerja Pemda: Pendekatan Manajemen dan Kebijakan. Makalah. Yogyakarta.

Mutopadidjadja, AR. 2002. Manajemen Kebijakan Publik. LAN. Jakarta.

Naihasy, H. Syharin. 2006. Kebijakan Publik (public Policy) Menggapai Masyarakat Madani. Mida Pustaka. Yogyakarta.

Nugroho Riant.2003. Kebijakan Publik Formulasi, Implementasi dan Evaluasi.Gramedia. Jakarta.

Pasolong, Harbani. 2008. Teori Administrasi Publik.Alfabeta. Bandung. 
Parson, Wayne. 2006-cetakan kedua. Public Policy. Pengantar Teori dan Praktek Analisis Kebijakan. Kencana. Jakarta.

Subarsono, AG. 2008. Analisis Kebijakan Publik Konsep, Teori dam Aplikasi. Pustaka Pelajar.Yogyakarta.

Suryadi, Soleh. 2009-cetakan kedua. Administrasi Publik dan Otonomi Daerah. Prisma Press. Bandung.

Tachan. 2008. Implementasi Kebijakan Publik. TRUENRTH Bandung.

Tangkilisan, Hessel Nogi S. 2003. Kebijakan Publik Untuk Pemimpin Berwawasan Nasional. Balairung. Yogya.

Thoha, Miftah. 1993. Perilaku Organisasi: Konsep Dasar dan Aplikasinya. Jakarta: Rajawali Pers. 2008. Manajemen Kepegawaian di Indonesia. Jakarta : Kencana. . 2008. Ilmu Administrasi Publik Kontempoler. Kencana Prenada Media Group. Jakarta.

Wahab, Solichin Abdul. 2004. Analisis Kebijaksanaan Dari Formulasi Ke Implementasi Kebijaksanaan Negara; Edisi Kedua. PT Bumi Aksara.Jakarta.

Wibawa, Samodra. 1994. Kebijakan Publik. Intermedia. Jakarta.

Wibisono, Dermawan. 2006. Manajemen Kinerja. Erlangga. Jakarta.

Widodo. 2007. Manajemen Kinerja:Edisi Kedua. PT. Raja Grafindo Persada. Jakarta. 2009. Analisis Kebijakan Publik.Bayumedia.Malang.

\section{DOKUMEN-DOKUMEN}

Undang-Undang Nomor 32 Tahun 2004 tentang Otonomi Daerah

Peraturan Daerah Kabupaten Subang Nomor 13 Tahun 2009 Tentang Ketertiban, Kebersihan dan Keindahan.

Surat Nomor 300/224/Sat.Pol.PP/2008 Tentang Perihal Laporan Hasil Operasi Pedagang Kaki Lima (PKL) 